\title{
MEDIAL FEMORAL CONDYLE CORTICOPERIOSTEAL FLAP: ANATOMIC STUDY
}

\author{
RETALHO CORTICOPERIOSTEAL DO CÔNDILO \\ FEMORAL MEDIAL: ESTUDO ANATÔMICO
}

\author{
Gustavo Bersani Silva ${ }^{1}$, Matheus Teotonio Vellosa ${ }^{1}$, Alvaro Baik $C_{\text {ho }}{ }^{1}$, Raquel Bernardelli lamaguchi da Costa ${ }^{1}$, \\ Olavo Pires de Camargo ${ }^{1}$, Rames Mattar Júnior ${ }^{1}$
}

1. Instituto de Ortopedia e Traumatologia, Hospital das Clinicas (HCFMUSP), Faculdade de Medicina, Universidade de São Paulo, São Paulo, SP, Brazil.

\section{ABSTRACT}

Objective: The medial femoral condyle corticoperiosteal flap is irrigated by the descending genicular artery, and when this is absent, by the superior medial genicular artery. The descending genicular artery divides into the muscular, saphenous, and osteoarticular branches. The objective of this study was to describe the variables involved in the dissection of the medial femoral condyle flap. Methods: Thirty thighs from 20 cadavers were dissected and the following variables were recorded: age, height, weight, thigh length, presence of the descending genicular artery, whether the saphenous branch originated from the descending genicular artery, the length of the branches originating from the descending genicular artery, and the diameter of the descending genicular artery and the vena comitans. Results: The descending genicular artery was present in $93.3 \%$ of the specimens (28/30). The saphenous branch originated from this artery in $76.7 \%$ of the dissections (23/70). The mean distance between the origin of the descending genicular artery and the knee joint was 13.4 $\mathrm{cm}( \pm 1.4)$, the mean length of the descending genicular artery was $7.5 \mathrm{~cm}( \pm 1.5)$, the mean diameter of the descending genicular artery was $1.9 \mathrm{~mm}( \pm 0.3)$, and the mean diameter of the vena comitans was $1.7 \mathrm{~mm}( \pm 0.3)$. Conclusion: The vascularized medial femoral condyle is a versatile option for reconstruction of musculoskeletal injuries. It allows transference of bone associated with muscle and skin, which are each nourished by independent branches. Level of Evidence IV; Case series.

Keywords: Surgical flaps. Microsurgery. Reconstruction. Arteries/ anatomy and histology. Thigh/ anatomy and histology.

\section{RESUMO}

Objetivo: O retalho ósseo vascularizado do côndilo femoral medial deve sua irrigação à artéria genicular descendente e, na ausência desta, à artéria genicular superior medial. A artéria genicular descendente comumente ramifica-se em: ramo muscular, safeno e osteoarticular. O estudo teve por objetivo analisar as variáveis relativas à dissecção do retalho ósseo do côndilo femoral medial. Métodos: Foram dissecados 30 joelhos (20 cadáveres), registrando-se: idade; estatura; peso; comprimento da coxa; presença da artéria genicular descendente; se o ramo safeno tem origem na artéria genicular descendente; comprimento dos ramos da artéria genicular descendente e os diâmetros da artéria genicular descendente e veia comitante. Resultados: A artéria genicular descendente esteve presente em 93,3\% dos espécimes (28/30). O ramo safeno originou-se da artéria genicular descendente em 76,7\% das dissecções (23/70). Distância entre origem da artéria genicular descendente e interlinha articular $=13,4( \pm 1,4) \mathrm{cm}$, comprimento da artéria genicular descendente $=7,5( \pm 1,5) \mathrm{cm}$, diâmetro da artéria genicular descendente $=1,9( \pm 0,3) \mathrm{mm}$, diâmetro da veia comitante $=1,7( \pm 0,3) \mathrm{mm}$. Conclusão: O retalho ósseo vascularizado do côndilo femoral medial mostrou-se a opção versátil para reconstrução de lesões do sistema músculo-esquelético. Permite a elevação de retalho ósseo associado à pele e tecido muscular, cada qual nutrido por ramos independentes. Nível de Evidência IV; Série de casos.

Descritores: Retalhos cirúrgicos. Microcirurgia. Reconstrução. Artérias/anatomia e histologia. Coxas/anatomia e histologia.

Citation: Silva GB, Vellosa MT, Cho AB, Costa RBI, Camargo OP, Mattar Júnior R. Medial femoral condyle corticoperiosteal flap: anatomic study. Acta Ortop Bras. [online]. 2018;26(3):179-82. Available from URL: http://www.scielo.br/aob.

\section{INTRODUCTION}

Vascularized bone flaps in skeletal reconstructions represent an important tool in managing traumatic, cancer-related, or congenital injuries that challenge surgeons who perform reconstructive surgery. ${ }^{1}$ In 1974, Ostrüp and Fredrickson ${ }^{2}$ reported the first free transfer of vascularized bone tissue. However, at this time there are comparatively less options for microsurgical transfer of bone tissue compared with the wide variety of skin flaps which have been described: ${ }^{3}$ vascularized transplant of the scapula, humerus, rib, radius, iliac crest, and fibula are some examples.

Cortico-periosteal grafting of the medial femoral condyle was described in English by Sakai et al., ${ }^{4}$ and has received increasing

All authors declare no potential conflict of interest related to this article.

Work conducted at the Hospital das Clínicas da Faculdade de Medicina de Ribeirão Preto da Universidade de São Paulo, SP, Brazil. Correspondence: Rua Dr. Ovídio Pires de Campos, 333, Cerqueira Cesar, São Paulo, SP, Brazil. 05403-010. gustavo.bersani@hc.fm.usp.br 
attention because of the ease of dissection, long pedicle, minimal morbidity, and possibility to transfer vascularized cortical bone with the periosteum, ${ }^{5-8}$ skin, muscle, and joint cartilage. ${ }^{9}$

The medial femoral condyle vascularized bone flap is irrigated by the descending genicular artery (DGA); when this artery is not present, it is irrigated by the superior medial genicular artery (SMGA), ${ }^{4}$ both of which stem from the superficial femoral artery (SFA). The classic description of the DGA system cites three main branches: the muscular branch (MB) for the vastus medialis muscle, the saphenous branch (SB) that irrigates vast area of leg skin, and the osteoarticular branch (OAB), which nourishes the periosteum, bone, and subchondral region.5,10 The common theoretical origin of these branches provides great versatility in reconstruction of multiple tissues (periosteum, bone, subchondral region, muscle, and skin, for example) supplied by a single potential pedicle. ${ }^{11}$

Over the last 25 years, various clinical applications of this flap have been described, including treatment of pseudoarthrosis of the arm, ${ }^{4,5}$ bone loss in the femur, ${ }^{12}$ tibia,, 813 foot, ${ }^{5}$ and skull..$^{14,15}$

However, questions remain about variability in the origin of the $D G A$, its ramifications in the $\mathrm{MB}, \mathrm{SB}$, and $\mathrm{OAB},{ }^{15}$ the length of these vessels, and the diameter of the main artery and veins at their origins. These questions led to the realization of this anatomic study.

\section{MATERIALS AND METHODS}

This study was approved by the institutional review board (Process 098/15).

Thirty legs from fresh male adult cadavers (aged 18 years and above) obtained from the "Serviço de Verificação de Óbitos" (SVO) were dissected. Individuals exhibiting injury or previous surgery in the legs were excluded.

The dissections were conducted systematically in the following manner:

- The size of the femur (from the greater trochanter to the joint interline of the knee) was recorded, along with the cadaver's height and age.

- The cadaver was positioned in dorsal decubitus with the leg rotated externally and hip abducted.

- A longitudinal incision was made in the medial and distal portions of the thigh along the longest axis of the vastus medialis muscle. (Figure 1)

- The vastus medialis muscle fascia was incised and the muscle moved away in a forward direction. The sartorius muscle was also isolated and moved away in a posterior direction.

- The DGA (or the SMGA if the DGA was not present) was identified and its origin in the superficial femoral artery defined.

- The anatomical parameters of these vessels were noted with regard to origin, length, and branching.

- The diameters of the DGA and the vena comitans were recorded, along with the SMGA when the DGA was absent, and the saphenous artery (SA) when present.

All measurements were taken with a tape measure, a ruler with millimeter increments, and a precision pachymeter. The diameter of the DGA, SMGA, and SA were measured through their cross sections, using the proximal portion of the vessel immediately where it originated from the SFA. A small segment of the sectioned

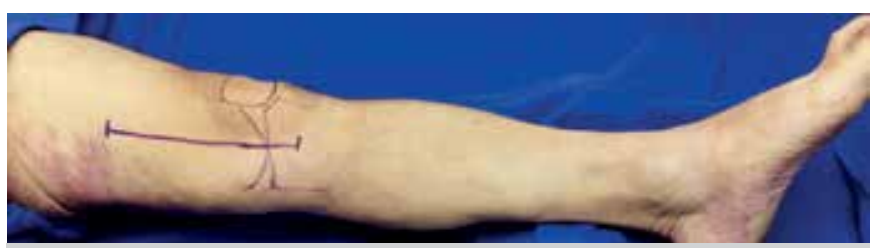

Figure 1. Incision site for dissection of the osseous flap of the medial femoral condyle. portion was incised longitudinally to measure the circumference of the vessel with a pachymeter.

The variables are summarized in Table 1.

Based on previous anatomic studies, 20 to 30 specimens were considered a sufficient number to evaluate the proposed parameters. ${ }^{11,16,17}$ Because this was a cross-sectional observational and descriptive study, we used the Pearson coefficient to measure the correlation between the continuous quantitative variables. The normality of data was evaluated using the Shapiro-Wilk test and analysis of the histograms. The data were presented as means, minimum value, maximum value, and standard deviation. A 5\% significance level $(p<0.05)$ was considered. SPSS version 22.0 software (SPSS Inc, Chicago, IL, USA) was used for the statistical analysis.

\begin{tabular}{|c|c|}
\hline Laterality & Right or left knee \\
\hline Age & Age in years according to SVO annotation \\
\hline Height & Height in centimeters according to SVO annotation \\
\hline Weight & Weight in kilograms according to the SVO annotation \\
\hline Thigh length & Thigh length: from greater trochanter to joint interline $(\mathrm{cm})$ \\
\hline DG present? & Is the descending genicular artery present: Yes or No? \\
\hline MB present? & $\begin{array}{l}\text { Is the muscular branch of the descending } \\
\text { genicular artery present: Yes or No? }\end{array}$ \\
\hline DG-J & $\begin{array}{l}\text { Descending genicular-joint interline: distance } \\
\text { between the origin of the descending genicular } \\
\text { artery from the femoral artery and the tibial-femoral joint } \\
\text { interline - the most distal portion of the medial condyle }(\mathrm{cm})\end{array}$ \\
\hline DG-MB & $\begin{array}{l}\text { Descending genicular - branch to the vastus medialis } \\
\text { muscle: distance between the origin of the DGA from de } \\
\text { femoral artery and the branch for the vastus medialis }(\mathrm{cm})\end{array}$ \\
\hline $\begin{array}{l}\text { Saphenous } \\
\text { branch DG? }\end{array}$ & $\begin{array}{l}\text { Does the saphenous branch originate from the } \\
\text { descending genicular artery - Yes or no? }\end{array}$ \\
\hline $\begin{array}{l}\text { DG-Saphenous } \\
\text { Branch }\end{array}$ & $\begin{array}{l}\text { Descending genicular - saphenous branch: distance } \\
\text { Branch between the origin of the DGA from de femoral } \\
\text { artery and the origin of the saphenous branch }(\mathrm{cm})\end{array}$ \\
\hline $\begin{array}{l}\text { Saphenous } \\
\text { Artery-Jl }\end{array}$ & $\begin{array}{l}\text { Saphenous Artery-Jl: distance between the origin of the } \\
\text { saphenous artery from the femoral artery and the tibial-femoral } \\
\text { joint interline - the most distal portion of the medial condyle }(\mathrm{cm})\end{array}$ \\
\hline MB length & $\begin{array}{l}\text { Length of the branch to the vastus medialis } \\
\text { muscle: distance between the efferent MB from } \\
\text { the DGA and the muscle surface }(\mathrm{cm})\end{array}$ \\
\hline DG-periosteum & $\begin{array}{l}\text { Descending genicular - periosteum: distance between the origin } \\
\text { of the descending genicular artery from the femoral artery and } \\
\text { the first branch to the periosteum of the medial condyle }(\mathrm{cm})\end{array}$ \\
\hline SMGA length & $\begin{array}{l}\text { Length of the superior medial genicular artery: distance } \\
\text { from the origin of the superior medial genicular artery } \\
\text { to the first branch to the periosteum }(\mathrm{cm})\end{array}$ \\
\hline Diam DGA & Diameter of the descending genicular artery $(\mathrm{mm})$ \\
\hline Diam DGV & Diameter of the descending genicular vein $(\mathrm{mm})$ \\
\hline Diam SA & $\begin{array}{l}\text { Diameter of the saphenous artery originating directly } \\
\text { from the superficial femoral artery }(\mathrm{mm})\end{array}$ \\
\hline Diam SMG & Diameter of the SMGA at its origin (mm) \\
\hline
\end{tabular}

\section{RESULTS}

We dissected 17 left knees and 13 right knees from 20 male individuals. The mean age of the specimens was 69.1 years (50-93; $\pm 14.0)$, the mean height was $171.7 \mathrm{~cm}(162-183 ; \pm 5.1)$ and mean weight was $65.9 \mathrm{~kg}(35-105 ; \pm 15.4)$. The mean thigh length was $42.8 \mathrm{~cm}(40.2-45.5 ; \pm 1.6)$

The descending genicular artery (DGA) was present in $93.3 \%$ of the specimens (28/30), originating in the superficial femoral artery (SFA). (Figure 2) The periosteum of the medial femoral condyle was nourished by the superior medial genicular artery (SMGA) in the two remaining cases $(2 / 30 ; 6.7 \%)$. The mean DGA length was $7.5 \mathrm{~cm}(4.9-11.4 ; \pm 1.5)$.

The mean distance between the origin of the DGA and the tibial-femoral joint interline (J) was $13.4 \mathrm{~cm}(10.6-17.0 ; \pm 1.4)$. The SB originated from 


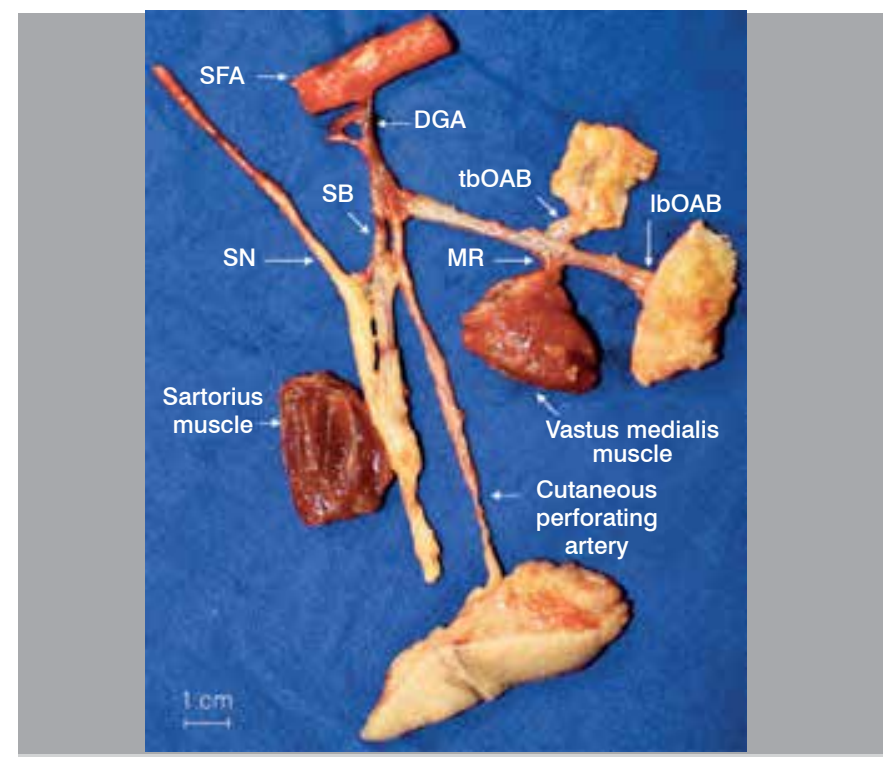

Figure 2. Dissection of the DGA system in its most common conformation. In this dissection, the tbOAB irrigated the periosteum, while the IbOAB nourished the bone of the medial femoral condyle.

the DGA in $73.3 \%$ of the dissections (22/30). The mean distance between the origin of the DGA and the SB was $1.2 \mathrm{~cm}(0-2.6 ; \pm 0.7)$. The mean distance between the origin of the DGA and the MB was $2.6 \mathrm{~cm}$ (0-6.6; \pm 1.6$)$. The mean length of the MB was $0.9 \mathrm{~cm}(0.3-1.5 ; \pm 0.3)$ and the average length of the $\mathrm{OAB}$ was $4.8 \mathrm{~cm}(2.3-7.6 ; \pm 1.4)$. The mean diameter of the DGA was $1.9 \mathrm{~mm}(1.3-2.5 ; \pm 0.3)$ and the mean diameter of the vena comitans vein was $1.7 \mathrm{~mm}(1.2-2.4 ; \pm 0.3)$. In eight knees, the SB did not originate from the DGA; the SA was seen to branch directly from the SFA in seven cases (7/30; 23.3\%) and the SA came from the SMGA in one case (1/30; 3.3\%). (Figure 3) In these eight knees, the SA originated an average of $14.5 \mathrm{~cm}$ (12.3-15.9; \pm 1.1$)$ above the Jl.

The mean length of the SB (or SA when originated directly from the SFA) exceeded eight centimeters. The mean diameter of the SA, when present, was $1.2 \mathrm{~mm}(1.1-1.5 ; \pm 0.2)$. The mean length and diameter of the SMGA were $4.1 \mathrm{~cm}(3.6-4.6 ; \pm 0.4)$ and $1.7 \mathrm{~mm}$ (1.6-1.7; \pm 0.1$)$, respectively.

The DGA derived from the superficial femoral artery and gave rise to the saphenous branch and osteoarticular branch (Figure 4) as classically described, in $73.3 \%$ of the dissections (22/30).

All the variables collected showed normal distribution after the Shapiro-Wilk test was applied and the histograms were analyzed. No statistically significant association was found between the variables studied and the laterality, height, femur length, or age. (Figure 4)

\section{DISCUSSION}

Since the medial femoral condyle flap technique was conceived, ${ }^{4}$ a number of factors have contributed to its growing popularization, namely: ${ }^{7-9,15,18}$

- The relative simplicity of dissection, since the vascular pedicle is located immediately under the vastus medialis muscle, which is located on the surface of the medial face of the thigh;

- The patient is positioned in the usual position, in dorsal decubitus, with the leg externally rotated and abducted;

- The surgical scar is located on the inner surface of the thigh, where it can be easily covered;

- A tourniquet can be used for dissection, providing vessels of a caliber that permit microsurgical anastomosis;

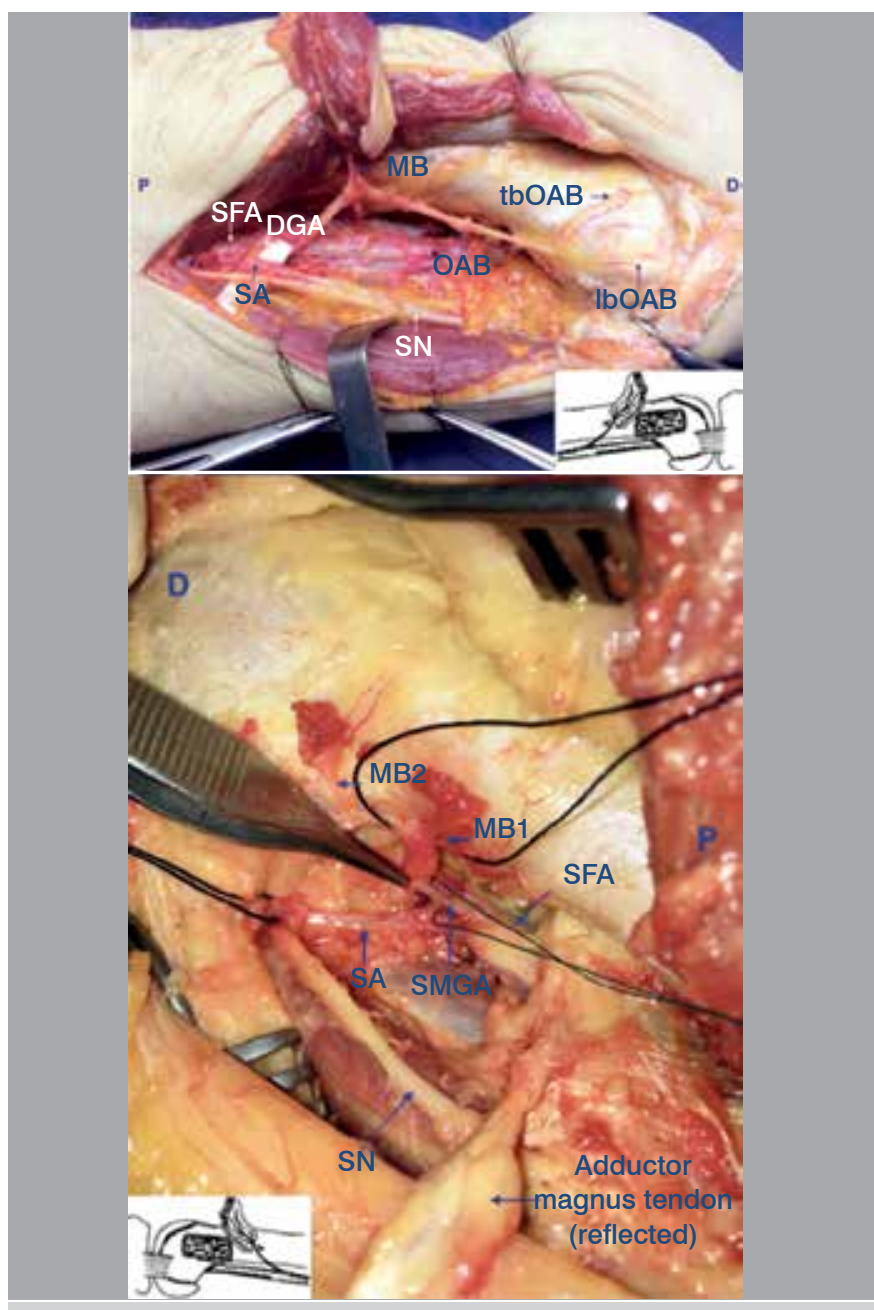

Figure 3. SA originating from the SFA (above) and SMGA (below). P: proximal, D: distal.

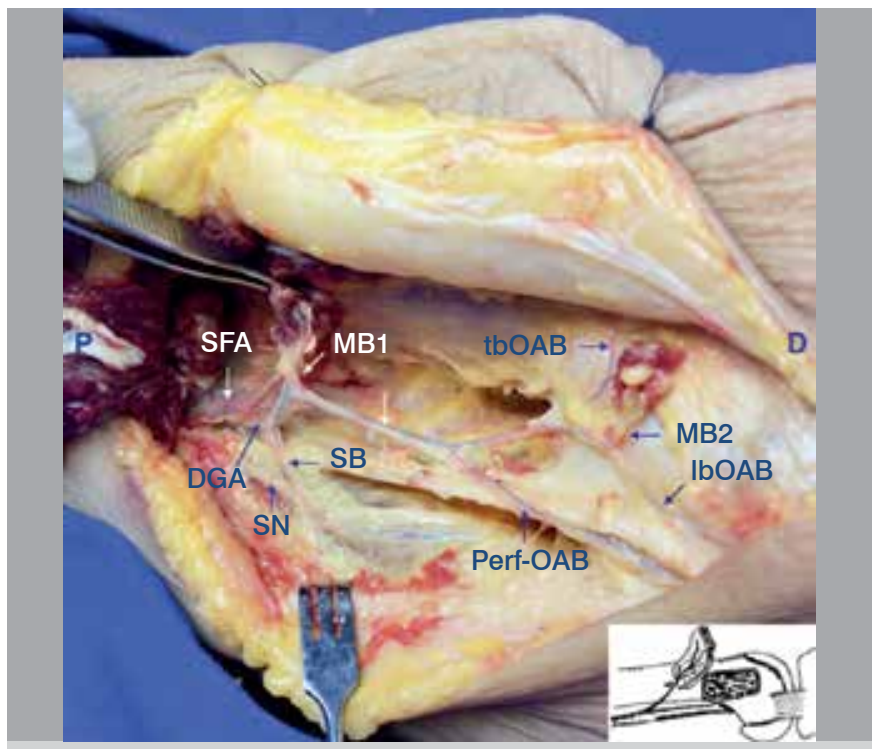

Figure 4. Standard conformation of the DGA system and its branches. Perf-OAB = the artery perforating the skin from the $O A B$ of the $D G A$; tbOAB: transverse branch of the osteoarticular branch of the DGA; IbOAB: longitudinal branch of the osteoarticular branch of the DGA; MB1 = First muscular branch; $\mathrm{MB} 2=$ Second muscular branch. P: proximal, D: distal. 
- Multiple tissues can be transplanted which are potentially supplied by a single vascular pedicle, notably the periosteum, bone and cartilage of the medial femoral condyle, skin of the medial aspect of the knee and leg, vastus medialis muscle, and saphenous nerve. These advantages are especially interesting compared to existing vascularized bone graft options such as grafts from the fibula, rib, scapula, or iliac crest, for example. ${ }^{3}$

Despite its advantages, the biggest impediments to more frequent use of this type of graft are the limited volume of cortico-periosteal tissue that can be transferred, and the anatomical variability of the vascularization of the different tissues of the region. ${ }^{8,19}$

Sakai et al. ${ }^{4}$ reported that preserving the innermost layer of the periosteum (cambium layer) is essential for maintaining osteogenic potential in cortico-periosteal transplants, which is why the isolated transfer of periosteal tissue without a thin layer of cortical bone produces poorer results with regard to osseous consolidation. Martin et al. ${ }^{14}$ suggested the use of bone grafts measuring up to 8.0 or $9.0 \mathrm{~cm}$ in length to ensure adequate vascularization of the transferred segment and preserve the structural integrity of the femur by not violating the diaphyseal portion of this bone, which reduces the risk of fracture. Brandtner et al. ${ }^{15}$ described the transfer of a bone graft measuring $15 \times 4 \times 1 \mathrm{~cm}$ which resulted in a fracture of the donor femur; these authors suggested bone fragments of up to $3.0 \mathrm{~cm}$ with a small island of skin (up to $4.0 \mathrm{~cm}$ wide) as ideal, allowing primary closure of the donor area and a lower rate of postoperative complications. The preference to transfer reduced bone volume, whether associated with cartilage or not and with a small island of skin, explains the preference for the vascularized osseous graft of the medial femoral condyle for reconstructions of the scaphoid and lunate, pseudoarthrosis of the upper limb with little bone loss or defects of the head and neck, which are the most common uses of this flap in the literature. $4,7,9,14,15,18$

The anatomical variability of the irrigation to the periosteum of the medial femoral condyle and neighboring tissues discourages the use of grafts based on vessels from the region, since when the descending genicular artery is absent the pedicle (which is then based on the superior medial genicular artery) becomes shorter and less versatile, because the classical description does not encompass transfer of a skin island based on this vessel. ${ }^{11}$

Hertel and Masquelet, ${ }^{13}$ Cavadas and Landin, ${ }^{8}$ and other authors ${ }^{11,15,20}$ conducted the largest anatomical and clinical series in the literature, studying between 20 and 107 femurs, and reported the presence of the DGA to range from 79 to $100 \%$. The current anatomical study, which analyzed data from 30 knees of fresh human cadavers, demonstrated the presence of the DGA in most of the specimens (28/30; $93.3 \%$ of dissections).

It is noteworthy that in all the knees studied in this series, as well as the reports in the literature, ${ }^{4,5,8,11,13,15,20}$ microsurgical transfer of vascularized bone tissue alone is always possible, since when the DGA is absent the SMGA is always present, irrigating the periosteum of the medial femoral condyle. Even though it is shorter (mean SMGA length was 4.1 $\mathrm{cm}$, versus $7.5 \mathrm{~cm}$ for DGA), the SMGA is sufficient for microsurgical anastomosis, with an average arterial diameter of $1.7 \mathrm{~mm}$.

We believe that the low morbidity and the constant anatomy of the periosteal vascularization of the medial femoral condyle are the two main features that make this technique attractive. At the same time, anatomical variations in the saphenous and muscular branches are important complicating factors to be considered when planning grafts containing multiple tissues. Preoperative imaging studies (angiography, angio-CT) which can define the vascular anatomy of the region are useful in preparing for these reconstructions.

\section{CONCLUSION}

The medial femoral condyle vascularized bone flap is a versatile option, with simple dissection and relatively constant anatomy for reconstruction of musculoskeletal injuries. Its irrigation from the descending genicular artery (or the superior medial genicular artery if the descending genicular artery is absent) allows transfer of the corticoperiosteal flap with associated skin and muscle tissue, each of which nourished by independent branches in most cases.

AUTHORS' CONTRIBUTIONS: Each author made significant individual contributions to this manuscript. GBS (0000-0002-8684-4479)*: conducted the dissections, drafted the text, and participated in updating and revision; MTV (0000-0002-4694-6112)* assisted in the dissections; ABC (0000-0002-30994750)*: revised the text; RBI (0000-0002-8965-5147)*: conducted the statistical analysis and revised the text; OPC (0000-0002-1128-7292)*: revised the text; RMJ (0000-0003-4202-4652)*: conceived the study and participated in drafting and revising the text. All authors approved the final version of the manuscript. *ORCID (Open Researcher and Contributor ID).

\section{REFERENCES}

1. Finley JM, Acland RD, Wood MB. Revascularized periosteal grafts--a new method to produce functional new bone without bone grafting. Plast Reconstr Surg. 1978:61(1):1-6.

2. Ostrup LT, Fredrickson JM. Distant transfer of a free, living bone graft by microvascular anastomoses. An experimental study. Plast Reconstr Surg. 1974;54(3):274-85

3. Malizos KN, Dailiana ZH, Innocenti M, Mathoulin CL, Mattar R, Sauerbier M. Vascularized bone grafts for upper limb reconstruction: Defects at the distal radius, wrist, and hand. J Hand Surg Am. 2010;35(10):1710-8.

4. Sakai K, Doi K, Kawai S. Free vascularized thin corticoperiosteal graft. Plas Reconstr Surg. 1991;87(2):290-8.

5. Doi K, Sakai K. Vascularized periosteal bone graft from the supracondylar region of the femur. Microsurgery. 1994;15(5):305-15.

6. Choudry UH, Bakri K, Moran SL, Karacor Z, Shin AY. The vascularized medial femoral condyle periosteal bone flap for the treatment of recalcitrant bony nonunions. Ann Plast Surg. 2008;60(2):174-80.

7. Jones DB, Bürger H, Bishop AT, Shin AY. Treatment of scaphoid waist nonunions with an avascular proximal pole and carpal collapse. A comparison of two vascularized bone grafts. J Bone Joint Surg Am. 2008;90(12):2616-25.

8. Cavadas PC, Landín L. Treatment of recalcitrant distal tibial nonunion using the descending genicular corticoperiosteal free flap. J Trauma. 2008:64(1):144-50.

9. Bürger HK, Windhofer C, Gaggl AJ, Higgins JP. Vascularized medial femoral trochlea osteochondral flap reconstruction of advanced kienböck disease. J Hand Surg Am. 2014;39(7):1313-22.

10. Fuchs B, Steinmann SP, Bishop AT. Free vascularized corticoperiosteal bone graft for the treatment of persistent nonunion of the clavicle. J Shoulder Elbow Surg. 2005;14(3):264-8.

11. Sananpanich K, Atthakomol P, Luevitoonvechkij S, Kraisarin J. Anatomical variations of the saphenous and descending genicular artery perforators Cadaveric study and clinical implications for vascular flaps. Plast Reconst Surg. 2013;131(3):363e-72e.

12. Guzzini M, Calderaro C, Guidi M, Civitenga C, Ferri G, Ferretti A. Treatment of a femur nonunion with microsurgical corticoperiosteal pedicled flap from the medial femoral condyle. Case Rep Orthop. 2016;2016:5125861.

13. Hertel R, Masquelet AC. The reverse flow medial knee osteoperiosteal flap for skeletal reconstruction of the leg. Description and anatomical basis. Surg Radiol Anat. 1989;11(4):257-62

14. Martin D, Bitonti-Grillo C, De Biscop J, Schott H, Mondie JM, Baudet J et al. Mandibular reconstruction using a free vascularised osteocutaneous flap from the internal condyle of the femur. Br J Plast Surg. 1991;44(6):397-402.

15. Brandtner C, Hachleitner J, Bottini GB, Buerger H, Gaggl A. Microvascular medial femoral condylar flaps in 107 consecutive reconstructions in the head and neck. Br J Oral Maxillofac Surg. 2016;54(6):614-8.

16. Iorio ML, Masden DL, Higgins JP. Cutaneous angiosome territory of the medial femoral condyle osteocutaneous flap. J Hand Surg Am. 2012;37(5):1033-41.

17. García-Pumarino R, Franco JM. Anatomical variability of descending genicular artery. Ann Plast Surg. 2014;73(5):607-11

18. Doi K, Oda T, Soo-Heong T, Nanda V. Free vascularized bone graft for nonunion of the scaphoid. J Hand Surg Am. 2000;25(3):507-19.

19. Yamamoto H, Jones DB, Moran SL, Bishop AT, Shin AY. The arterial anatomy of the media femoral condyle and its clinical implications. JHand Surg Eur Vol. 2010:35(7):569-74.

20. Huang D, Wang HW, Xu DC, Wang HG, Wu WZ, Zhang HR. An anatomic and clinical study of the adductor magnus tendon-descending genicular artery bone flap. Clin Anat. 2011;24(1):77-83. 